\title{
Pyroclastic Andesite Tile Melting during the First Two Seconds after the Explosion of the A-bomb at 8:15 a.m. on August 6, 1945 in Hiroshima
}

\author{
Martin RADVANEC*
}

\begin{abstract}
The extreme effect of the heat rays of the A-bomb explosion on August 6, 1945 at 8:15 a.m. in Hiroshima was studied on two tile fragments that had been excavated during the period from 1977 to 1982 from the west bank of Motoyasu River, about $100 \mathrm{~m}$ down the river from the Motoyasu bridge. A number of very hot and melted fragments, which the shock wave brought from buildings that were smashed at the hypocenter $1.318 \mathrm{~s}$ after the explosion, were deposited on the west bank of the river. The pieces of tile possibly came from the destroyed stone wall of the Sei Hospital, the Saikoji Temple, and/or the Sairenji Temple, and were quickly cooled by the river water.

The tile fragments were composed of andesitic pyroclastic rock and their surfaces were melted to a depth of $3.18 \mathrm{~mm}$. The glass crust had a variable andesite and basalt-andesite composition, which are the melt products of cristobalite and/or tridymite, pigeonite $\left(\mathrm{X}_{\mathrm{Fe}}=\mathrm{Fe} /\right.$ $(\mathrm{Fe}+\mathrm{Mg})=0.37-0.44)$, hornblende $\left(\mathrm{X}_{\mathrm{Fe}}=0.33-0.42\right)$, labradorite $\left(\mathrm{Ab}_{48.2-40.6} \mathrm{An}_{51.8-55.5} \mathrm{Or}_{0-3.9}\right)$, and $\mathrm{K}$-feldspar $\left(\mathrm{Ab}_{8.2} \mathrm{Or}_{91.8}\right)$. The temperature of $6287^{\circ} \mathrm{C}$ was calculated on the surface of an object at the hypocenter after the explosion, according to the depth of $3.18 \mathrm{~mm}$ of the melt and different depths and melting points of above mentioned minerals. This surface temperature was deduced by the extrapolating of the depth-temperature relationship obtained by the mineralrelicts between 2.68 and $3.18 \mathrm{~mm}$ of depth. According to the regression line $T=-1715.1 d+$ 6287 ( $d$ is the depth) with $R^{2}=0.989$, the temperature gradient in the andesite tile was $1715^{\circ} \mathrm{C} /$ $\mathrm{mm}$, reaching a depth from 2.86 to $3.18 \mathrm{~mm}$, where the volume of glass and volume of primary minerals (rock) are equal. For a depth of more than $3.64 \mathrm{~mm}$, the structure and mineral assemblage of pyroclastic andesite rock has an initial composition.
\end{abstract}

Key words : Hiroshima, A-bomb, hypocenter, temperature

\section{Introduction}

The topic of this study is the extreme effect of the heat rays on rock during the first two seconds after the A-bomb explosion in Hiroshima. The aim is to infer or expertly estimate the temperature at the hypocenter. For this purpose, two fragments of andesitic pyroclastic rock were chosen where relations between the different melting points of minerals and the depth of the melt were studied in detail. Fragments were directly exposed to extreme conditions such as heat rays, $\gamma$-radiation, and neutron radiation; however, the extreme heat rays and temperature had the dominant effect of melting the rock (Manhattan Engineer District, 1946; Shohno et al., 1978; Kamada, 2005; Burr, 2007).

The notice of bombing was announced from the

\footnotetext{
* State Geological Institute of Dionýz Štúr (address: Markušovská cesta 1, 05201 Spišská Nová Ves, Slovakia)
} 
dropped flyers a few days before bombing to the civil population about evacuating Hiroshima and Nagasaki. The atomic bomb was dropped at 8:15 a.m. on August 6, 1945 for the first time in the history of war conflicts. The bomb exploded $580 \mathrm{~m}$ above the Hiroshima center and released energy that is equal to 15 kilotons of regular trinitrotoluene explosives (Manhattan Engineer District, 1946; Burr, 2007). Half of the explosion energy was absorbed by the extreme pressure wave; $35 \%$ of energy was changed to heat rays, and $15 \%$ to radiation. From 15\% of energy absorbed by radiation, only $4.5 \%$ changed to $\gamma$-radiation, $0.5 \%$ to neutron radiation, and $10 \%$ was absorbed by residual radiation, which is also known as the "ash of death” (Shohno et al., 1978; Kamada, 2005).

At the moment of the explosion, the sky had elevated brightness, destroying eyesight with a blinding fireball, which was several millions of degrees Celsius at the burst point in the center. The fireball rapidly increased in volume; it lost its luminosity after $10 \mathrm{~s}$. In the meantime, the fireball underwent the following changes in size and temperature (Shohno et al., 1978): It had a diameter of about $28 \mathrm{~m}$ and a uniform temperature of about $300,000^{\circ} \mathrm{C}$ at $1 / 10,000$ of a second after the detonation; a diameter of about $180 \mathrm{~m}$ and surface temperature of about $1700^{\circ} \mathrm{C}, 1 / 100$ of a second later; a surface temperature of about $7000^{\circ} \mathrm{C}$ - rising again $-0.3 \mathrm{~s}$ later; a maximum diameter of about $280 \mathrm{~m}$ and surface temperature of about $5000^{\circ} \mathrm{C}, 1 \mathrm{~s}$ later; a surface temperature $1700^{\circ} \mathrm{C}$ again $3 \mathrm{~s}$ later, and thereafter it fell gradually. Ninety-nine percent of the thermal radiation from the fireball had a strong effect on the ground only from $1 / 100$ of a second to about $3 \mathrm{~s}$ after the detonation. The thermal radiation, with a wavelength longer than $186 \mathrm{~nm}$, was a mixture of ultraviolet rays, visible rays, and infrared rays (Shohno et al., 1978).

The flame from the fireball was glowing in all directions and heat rays on the ground surface ("ground zero" or hypocenter) affected buildings, stones, trees, and people for the first few seconds. This is the moment when the surface of roof tiles, stones, glass bottles, and iron objects melted, and the trees started to ignite from inside (Hiroshima
Peace Memorial Museum, 1994).

The melting caused bubbling or blistering of the dark green to black tiles with a porous surface that are commonly used for roofing, and was reported up to a distance of $975 \mathrm{~m}$ from the hypocenter (Glasstone and Dolan, 1977). In a laboratory, a test using an undamaged tile of similar blistering showed that the same result could be obtained by heating to $1800^{\circ} \mathrm{C}$ for a period of $4 \mathrm{~s}$. It was concluded that $975 \mathrm{~m}$ from the hypocenter, the tile attained a surface temperature of more than $1800^{\circ} \mathrm{C}$ for a period less than $4 \mathrm{~s}$ (Hirschfelder et al., 1950; Glasstone and Dolan, 1977). Another experiment on the roof tile shows a necessary surface melting temperature of $2000^{\circ} \mathrm{C}$ during exposure for $1 \mathrm{~s}$ (Hashiguchi, 1953). On the surface of the melted roof tiles, a similar experiment provided the minimum appraisal temperature between 1200 and $1250^{\circ} \mathrm{C}$. The roof tile was forced to heat for more than 10 minutes (Majima et al., 1953). This long impact time is not in accordance with the shock of heat rays impact on the Hiroshima surface.

The surface of granite tile and blocks appeared faint and ruffled from melted quartz and similar melting bubbles in an area $600 \mathrm{~m}$ from the hypocenter (Hiroshima Peace Memorial Museum, 1994). A temperature of $2000^{\circ} \mathrm{C}$ was estimated for the melting of the granite tombstone at that location (Nishina, 1951). At a distance of $630 \mathrm{~m}$ from the hypocenter the same melting temperature of $2000^{\circ} \mathrm{C}$ was estimated by Tsuzuki (1951) and by Tanaka (1953); however, $700 \mathrm{~m}$ from the hypocenter, Tsutsui (1953) appraised the temperature from 1200 to $1300^{\circ} \mathrm{C}$ for roof tile melting.

Due to the intensity of heat rays and thermal radiation, a very high temperature below the burst possibly attained surface temperatures of 3000 to $4000^{\circ} \mathrm{C}$ (Glasstone and Dolan, 1977; Hiroshima-shi, Nagasaki-shi Genbaku Saigaishi Henshu Iinkai, 1979; Sekimori, 1989; Hiroshima Peace Memorial Museum, 1994). The extreme thermal radiation energy of $99.6 \mathrm{cal} / \mathrm{cm}^{2}$ estimated by Shohno et al. (1978) at the hypocenter, explained why directly beneath the burst in the split second before the blast wave arrives, pedestrians 
simply vanished into smoke and ash.

According to the parameters of the explosion, the supersonic shock wave with a pressure of 35 ton on $1 \mathrm{~m}^{2}$ and a speed of $440 \mathrm{~m} / \mathrm{s}$ reached the surface after $1.318 \mathrm{~s}$ (Hiroshima Peace Memorial Museum, 1994). This brief interval is the travel time of the wave from the epicenter to the surface and it is the interval when the surface was effectively exposed to the extreme energy born at the epicenter. It is important to evaluate the brief length of exposure time to the heat rays to determine the thermal effect on the roof tile and objects in the hypocenter.

After the impact of the shock wave on the surface, the burning air implies broken and atomized melted roofs when buildings, trees, human bodies, and other objects were mixed with small fragments and dust. The explosion destroyed life; it was devastating for all functions of the city and most of the city was erased from surface of the Earth and a dry plain was created (Sekimori, 1989; Selden and Selden, 1997).

Studying the melting, changes in pyroclastic andesite tile and understanding of the temperature conditions that occurred during the first two seconds after the explosion, may allow a better understanding of the destructive power of the atomic bomb.

\section{Sample selection and analytical conditions of the microprobe}

Two samples (fragments of tile) of andesitic pyroclastic rock had been excavated, during the period from 1977 to 1982, by high school students (see acknowledgments) from the west bank of the Motoyasu River, about $100 \mathrm{~m}$ down the river from the Motoyasu bridge (Fig. 1). The west bank was in a unique position, having a natural cave and its right corner situated in the direction of the shock wave initiated from the epicenter. The very hot and melted steaming fragments that the shock wave brought from buildings smashed at the hypocenter was collected at the bank. The melted fragments were quickly cooled by the river water, which explains the conservation of the glass in situ without a melt flow on the surface (Figs. 1 and 2). Fragments having similar consolidated thicknesses of about $2 \mathrm{~cm}$, were regarded as pieces of roof tile or floor stone, which possibly came from the destroyed stone wall around the Sei Hospital, or from the Saikoji Temple, and/or from the Sairenji Temple at the hypocenter (Fig. 1). The platy rock tiles of andesite were used on a stone wall and the entrance gate of the Sei Hospital and their surface was markedly melted (Watanabe et al., 1953). A platy andesite rock found $40 \mathrm{~m}$ from the hypocenter at the top of the wall rock around the Sei Hospital possibly came from the KamiSuwa area in the Nagano prefecture (Watanabe et al., 1953).

From the mineral assemblage - cristobalitetridymite, hornblende, labradorite, K-feldspar and pigeonite $\mathrm{Wo}_{8-11} \mathrm{En}_{49-58} \mathrm{Fs}_{34-40}$ phenocrysts (Fig. 3; Table 1) - it was deduced that the fragments of pyroclastic andesitic tile came from common andesitic lavas in the Japanese islands (Kuno, 1950; Ito and Morimoto, 1956; Ishibashi, 1971).

The tile fragments were cut vertically across the melted surface to prepare polished thin sections. The glassy surface of fragments is wavy and the quenched glass part encloses air bubbles. The first mode of "empty" air bubbles occurred beneath the surface and in peaks of the wavy glass. Peaks extend from 1 to $2 \mathrm{~mm}$ over the flat melted surface (Fig. 2). In this case, the thickness of glass does not represent the depth of the original rock because of "empty" bubble content in the glass expanded by the growth of bubbles during shock melting. The second mode of "filled" air bubbles occurs sporadically in the glass. These bubbles are filled by relicts of cristobalitetridymite, K-feldspar, pigeonite, and fragments of glass, where the size of numerous relicts is a few microns (Fig. 4). These relicts are bonded at the internal part of bubbles, which are formed during the cooling of the melt, when the hot air liberated from the rock tears off and captures the relicts of minerals inside bubbles. Over the top of glass thickness no peaks of glass occurred where the "filled" bubbles are present. Therefore, this mode of bubbles does not modify the general thickness of glass, but rather represents the depth of the original rock (Fig. 4).

The thickness of the glassy crust was measured 


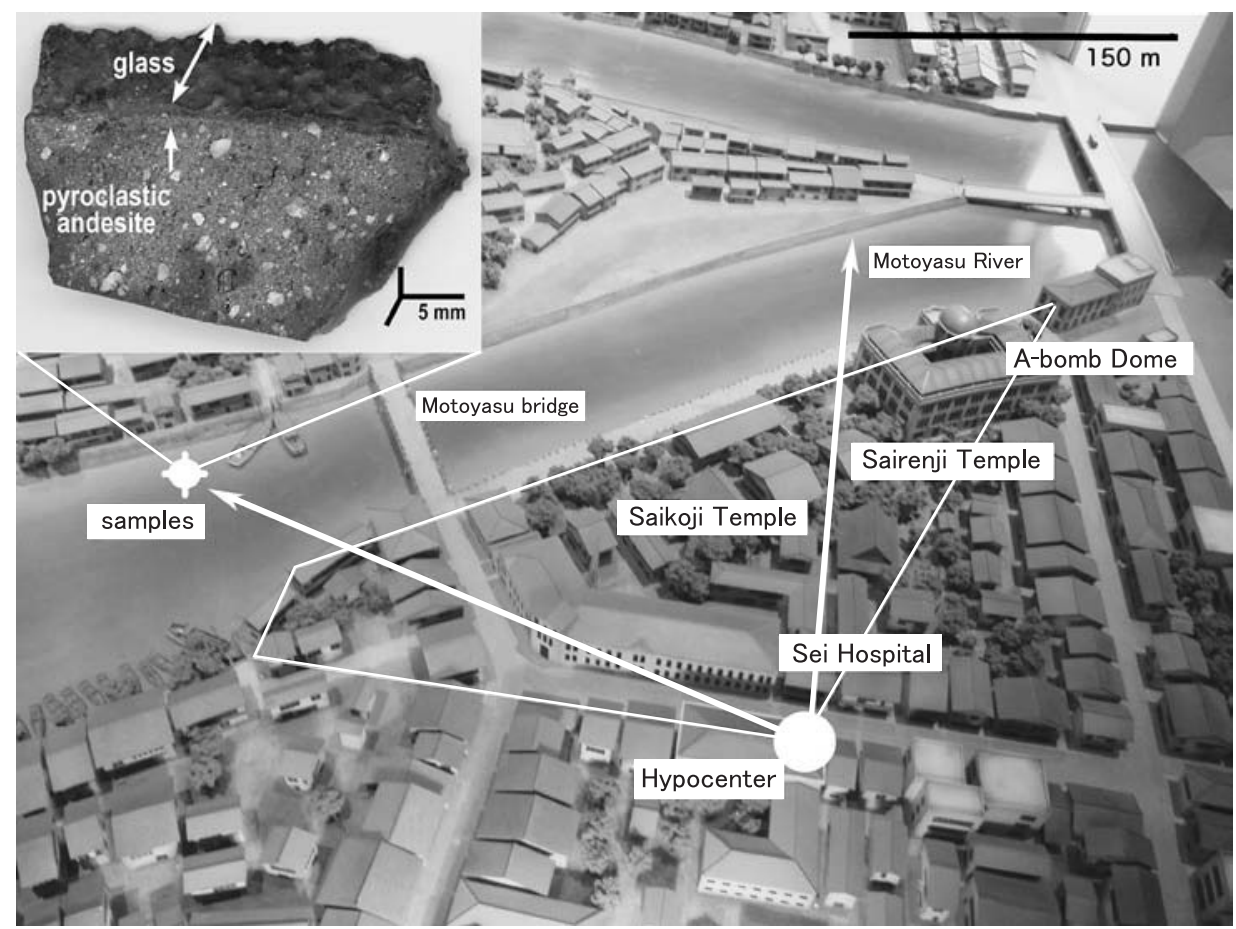

Fig. 1 View of the hypocenter of the A-bomb explosion (epicenter) at Hiroshima and sampling locality of the studied tile fragments in the Motoyasu River. Framed area represents the likely position of the tile at the time of the A-bomb explosion on buildings in area of the Saikoji Temple, the Sairenji Temple, and Sei Hospital. Arrows show direction of shock wave that transported the melted samples into the river from the hypocenter. Panoramic view of Hiroshima central area before the A-bombing, displayed at the Hiroshima Peace Memorial Museum, photo by T. Tamori.

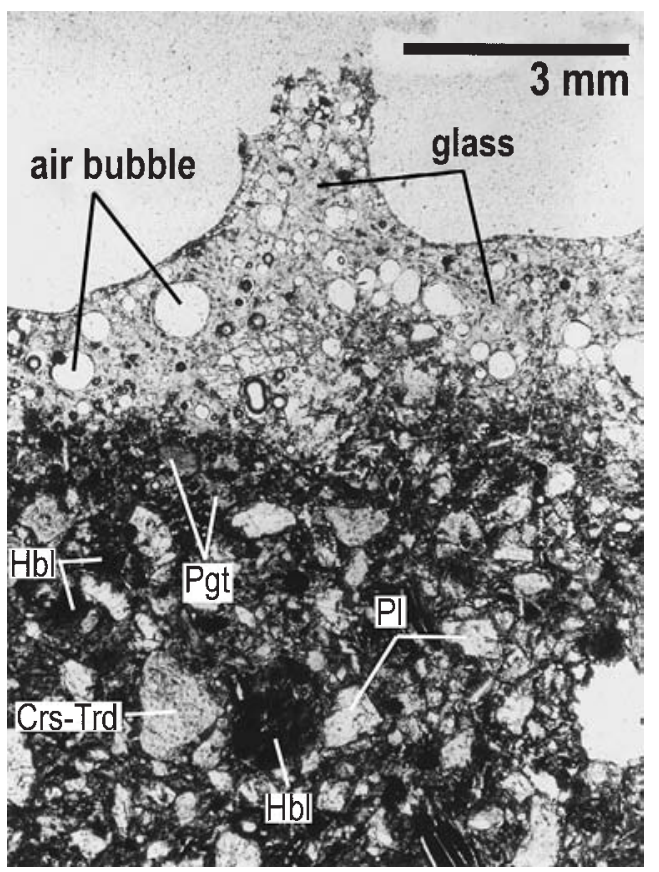

Fig. 2 Relationship between andesitic glass and mineral assemblage of the pyroclastic andesite tile in polarization microscope. $\mathrm{Hbl}$ - hornblende, Pgt - pigeonite, $\mathrm{Pl}$ - labradorite, Crs-Trd - cristobalite-tridymite. 


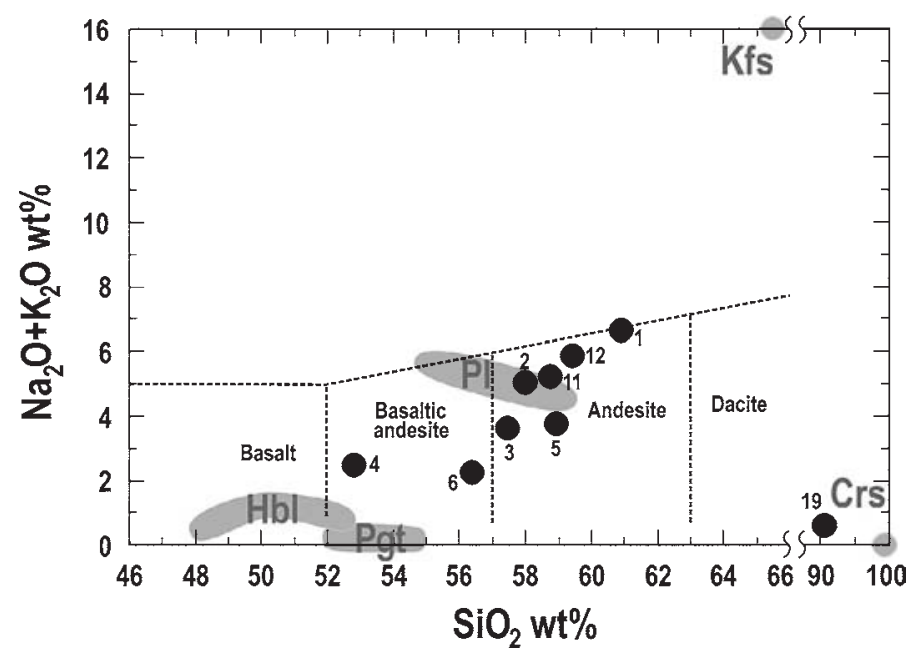

Fig. 3 Glass composition and hornblende ( $\mathrm{Hbl}$ ), pigeonite (Pgt), labradorite (Pl), K-feldspar (Kfs) and cristobalitetridymite (Crs) and their compared compositions in diagram $\mathrm{Na}_{2} \mathrm{O}+\mathrm{K}_{2} \mathrm{O}$ versus $\mathrm{SiO}_{2}$. Andesite, basalt-andesite, and dacite fields are after the classification of volcanic rocks (Le Bas et al., 1986). Analyses 1-6, 11-12, and 19 are in Table 1 and the exact depths of positions are in Fig. 4.

in 15 thin sections, excluding the peaks, with an optic microscope; the average depth was greater than $3 \mathrm{~mm}$. For the study in the microprobe, the representative cross cut was chosen having average depth, flat surface of melt without peaks, and empty air bubbles, respectively. The presence of the complete mineral assemblage (cristobalitetridymite, hornblende, labradorite, K-feldspar, pigeonite) determined which area was applicable for the study of the cross cut (Fig. 4).

Relationships between the mineral assemblages and melt were studied by a scanning electron microscope with an energy-dispersing X-ray analytical (EDS) system (KEVEX) at Kyoto University (Department of Mineralogy and Petrology). The chemical compositions of minerals and melt (glass) were determined using the Cameca SX 100 facility at the Central Laboratory of Electron Microprobe (CLEMP; WDS) at the State Geological Institute of Dionýz Štúr in Bratislava, Slovak Republic. A variety of natural minerals (wollastonite for $\mathrm{Ca}$ and $\mathrm{Si}$, rhodonite for $\mathrm{Mn}$, albite for $\mathrm{Na}$, orthoclase for $\mathrm{K}$, chromite for $\mathrm{Cr}$ ) and synthetic compounds (pure Ti-, $\mathrm{Al}-, \mathrm{Fe}-$, and $\mathrm{Mg}$-oxides for $\mathrm{Ti}, \mathrm{Al}, \mathrm{Fe}, \mathrm{Mg}$ ) were used as standards. The analytical parameters are as follows: accelerating voltage, $15 \mathrm{kV}$; beam current, $20 \mathrm{nA}$; beam diameter, 1-5 $\mu \mathrm{m}$; and $10 \mathrm{~s}$, counting times per element. The detection limit is better than $0.04 \mathrm{wt} \%$ for all analyzed elements including standard deviation (Table 1).

The detail measuring of the depth and relations between minerals and melt was performed in the cross sections being documented by the micro photos of the backscattered electron image (BEI). Individual photos in the cut were scanned with a scan window of $500 \mu \mathrm{m}$. The exact position of minerals and melt in the thin section was measured to $1 / 100$ of a millimetre precision because the width of the photo (BEI) is $11.5 \mathrm{~cm}$ (Fig. 4).

\section{Mineral assemblage of the tile and temperature of its melting}

The temperature of a melting tile on its surface was derived from the melting temperature of individual minerals in the pyroclastic andesite tile. The melting temperature designates the melting point, according to experimental results for a particular mineral.

\section{1) Glass}

On the pyroclastic andesite tile, the crust of glass has a markedly wide composition, where 
Table 1 Microprobe analyses of glass and minerals of tile (pyroclastic andesite). Points from 1 to 19 -analytical points in cross-section on Fig. 4.

\begin{tabular}{|c|c|c|c|c|c|c|c|c|c|c|}
\hline $\begin{array}{l}\text { Point } \\
\text { Mineral } \\
\text { Place }\end{array}$ & $\begin{array}{c}1 \\
\text { glass } \\
\operatorname{rim}\end{array}$ & $\begin{array}{c}2 \\
\text { glass } \\
\text { rim-dark }\end{array}$ & $\begin{array}{c}3 \\
\text { glass } \\
\text { dark }\end{array}$ & $\begin{array}{c}4 \\
\text { glass } \\
\text { light }\end{array}$ & $\begin{array}{c}5 \\
\text { glass }\end{array}$ & $\begin{array}{c}6 \\
\text { glass }\end{array}$ & $\begin{array}{l}7 \\
\text { relict } \\
\quad ?\end{array}$ & $\begin{array}{c}8 \\
\text { K-feldsp. }\end{array}$ & $\begin{array}{c}9 \\
\text { pigeonite }\end{array}$ & $\begin{array}{l}19 \\
\text { glass } \\
\text { dark }\end{array}$ \\
\hline $\mathrm{SiO}_{2}$ & 60.91 & 57.39 & 57.47 & 52.81 & 58.92 & 56.40 & 45.08 & 65.21 & 54.54 & 91.30 \\
\hline $\mathrm{TiO}_{2}$ & 1.24 & 1.45 & 1.14 & 1.75 & 1.65 & 1.72 & 0.08 & 0 & 0.36 & 0.12 \\
\hline $\mathrm{Al}_{2} \mathrm{O}_{3}$ & 20.38 & 21.03 & 23.07 & 16.38 & 22.51 & 19.65 & 33.46 & 17.93 & 2.84 & 4.34 \\
\hline $\mathrm{FeO}$ & 4.09 & 5.32 & 3.37 & 14.84 & 3.19 & 9.31 & 4.92 & 0 & 19.46 & 1.23 \\
\hline $\mathrm{MnO}$ & 0.10 & 0.10 & 0.08 & 0.35 & 0.11 & 0.19 & 0.09 & 0 & 0.48 & 0.09 \\
\hline $\mathrm{MgO}$ & 1.51 & 3.12 & 2.15 & 10.28 & 0.87 & 5.56 & 1.50 & 0 & 18.81 & 0.98 \\
\hline $\mathrm{CaO}$ & 5.07 & 6.68 & 9.67 & 0.81 & 8.89 & 5.29 & 0.17 & 0 & 3.81 & 1.14 \\
\hline $\mathrm{Na}_{2} \mathrm{O}$ & 2.90 & 3.01 & 2.46 & 0.60 & 2.22 & 0.62 & 0.32 & 0.93 & 0.09 & 0.35 \\
\hline $\mathrm{K}_{2} \mathrm{O}$ & 3.76 & 2.06 & 1.17 & 1.86 & 1.54 & 1.64 & 0.24 & 15.70 & 0.09 & 0.42 \\
\hline Total & 99.96 & 100.16 & 100.58 & 99.68 & 99.90 & 100.38 & 85.86 & 99.77 & 100.48 & 99.97 \\
\hline $\mathrm{O}=$ & 100 & 100 & 100 & 100 & 100 & 100 & 100 & 8 & 6 & 100 \\
\hline $\mathrm{Si}$ & 34.620 & 32.854 & 32.468 & 31.461 & 33.319 & 32.477 & 28.804 & 3.015 & 2.034 & 46.857 \\
\hline $\mathrm{Ti}$ & 0.481 & 0.621 & 0.484 & 0.782 & 0.701 & 0.745 & 0.035 & 0 & 0.010 & 0.046 \\
\hline $\mathrm{Al}$ & 13.620 & 14.189 & 15.364 & 11.499 & 15.006 & 13.334 & 25.200 & 0.977 & 0.125 & 2.623 \\
\hline $\mathrm{Fe}$ & 1.946 & 2.542 & 1.593 & 7.392 & 1.511 & 4.480 & 2.630 & 0 & 0.607 & 0.528 \\
\hline $\mathrm{Mn}$ & 0.050 & 0.048 & 0.036 & 0.176 & 0.049 & 0.094 & 0.050 & 0 & 0.015 & 0.039 \\
\hline $\mathrm{Mg}$ & 1.280 & 2.660 & 1.805 & 9.124 & 0.729 & 4.774 & 1.430 & 0 & 1.046 & 0.750 \\
\hline $\mathrm{Ca}$ & 3.085 & 4.094 & 5.853 & 0.521 & 5.390 & 3.259 & 0.119 & 0 & 0.152 & 0.627 \\
\hline $\mathrm{Na}$ & 3.185 & 3.344 & 2.696 & 0.695 & 2.433 & 0.691 & 0.397 & 0.083 & 0.007 & 0.348 \\
\hline $\mathrm{K}$ & 2.731 & 1.502 & 0.838 & 1.412 & 1.116 & 1.205 & 0.195 & 0.926 & 0.004 & 0.275 \\
\hline Total & 61.031 & 61.854 & 61.137 & 63.062 & 60.254 & 61.059 & 58.860 & 5.001 & 4.000 & 52.093 \\
\hline
\end{tabular}

\begin{tabular}{|c|c|c|c|c|c|c|c|c|c|}
\hline $\begin{array}{l}\text { Point } \\
\text { Mineral } \\
\text { Place }\end{array}$ & $\begin{array}{c}10 \\
\text { relict } \\
\text { bubble }\end{array}$ & $\begin{array}{c}11 \\
\text { glass } \\
\text { dark }\end{array}$ & $\begin{array}{c}12 \\
\text { glass }\end{array}$ & $\begin{array}{c}13 \\
\text { hornblende } \\
\text { melt. dow } \\
\text { relict }\end{array}$ & $\begin{array}{c}14 \\
\text { pigeonite }\end{array}$ & $\begin{array}{c}15 \\
\text { labrador. } \\
\text { core }\end{array}$ & $\begin{array}{c}16 \\
\text { labrador. } \\
\text { rim }\end{array}$ & $\begin{array}{c}17 \\
\text { hornblende } \\
-(\mathrm{OH}) \\
\text { core }\end{array}$ & $\begin{array}{c}18 \\
\text { hornblende } \\
-(\mathrm{OH}) \\
\text { rim }\end{array}$ \\
\hline $\mathrm{SiO}_{2}$ & 41.06 & 58.73 & 59.41 & 51.29 & 52.21 & 55.03 & 59.33 & 52.40 & 48.22 \\
\hline $\mathrm{TiO}_{2}$ & 0.22 & 0.45 & 0.07 & 0.92 & 0.61 & 0 & 0.13 & 1.23 & 2.80 \\
\hline $\mathrm{Al}_{2} \mathrm{O}_{3}$ & 7.41 & 24.02 & 25.44 & 11.41 & 3.09 & 28.27 & 25.19 & 4.57 & 7.90 \\
\hline $\mathrm{FeO}$ & 3.24 & 1.85 & 2.54 & 9.27 & 21.84 & 0 & 0.50 & 13.79 & 16.44 \\
\hline $\mathrm{MnO}$ & 0.10 & 0.04 & 0.15 & 0.15 & 0.79 & 0 & 0 & 0.39 & 0.33 \\
\hline $\mathrm{MgO}$ & 1.10 & 1.13 & 1.14 & 10.43 & 15.66 & 0 & 0 & 13.91 & 12.35 \\
\hline $\mathrm{CaO}$ & 2.74 & 8.44 & 5.92 & 8.70 & 4.90 & 11.13 & 9.98 & 12.28 & 11.68 \\
\hline $\mathrm{Na}_{2} \mathrm{O}$ & 1.22 & 4.57 & 3.20 & 0.46 & 0.11 & 5.71 & 4.03 & 0.43 & 0.33 \\
\hline $\mathrm{K}_{2} \mathrm{O}$ & 1.31 & 0.64 & 2.69 & 0.65 & 0.15 & 0 & 0.59 & 0.42 & 0.21 \\
\hline Total & 58.40 & 99.87 & 100.56 & 93.28 & 99.36 & 100.14 & 99.75 & 99.42 & 100.26 \\
\hline $\mathrm{O}=$ & 100 & 100 & 100 & 23 & 6 & 8 & 8 & 23 & 23 \\
\hline $\mathrm{Si}$ & 39.130 & 33.041 & 33.181 & 7.478 & 2.003 & 2.480 & 2.655 & 7.479 & 6.930 \\
\hline $\mathrm{Ti}$ & 0.153 & 0.192 & 0.029 & 0.101 & 0.018 & 0 & 0.005 & 0.131 & 0.303 \\
\hline $\mathrm{Al}$ & 8.328 & 15.926 & 16.750 & 1.960 & 0.140 & 1.501 & 1.329 & 0.769 & 1.338 \\
\hline $\mathrm{Fe}$ & 2.584 & 0.869 & 1.187 & 1.131 & 0.701 & 0 & 0.019 & 1.646 & 1.975 \\
\hline $\mathrm{Mn}$ & 0.085 & 0.018 & 0.074 & 0.019 & 0.026 & 0 & 0 & 0.047 & 0.041 \\
\hline $\mathrm{Mg}$ & 1.564 & 0.945 & 0.956 & 2.267 & 0.896 & 0 & 0 & 2.959 & 2.646 \\
\hline $\mathrm{Ca}$ & 2.790 & 5.091 & 3.546 & 1.359 & 0.201 & 0.537 & 0.478 & 1.877 & 1.799 \\
\hline $\mathrm{Na}$ & 2.245 & 4.981 & 3.464 & 0.131 & 0.008 & 0.499 & 0.350 & 0.118 & 0.093 \\
\hline $\mathrm{K}$ & 1.593 & 0.464 & 1.921 & 0.121 & 0.007 & 0 & 0.034 & 0.077 & 0.039 \\
\hline Total & 58.472 & 61.527 & 61.108 & 14.567 & 4.000 & 5.017 & 4.870 & 15.103 & 15.164 \\
\hline
\end{tabular}




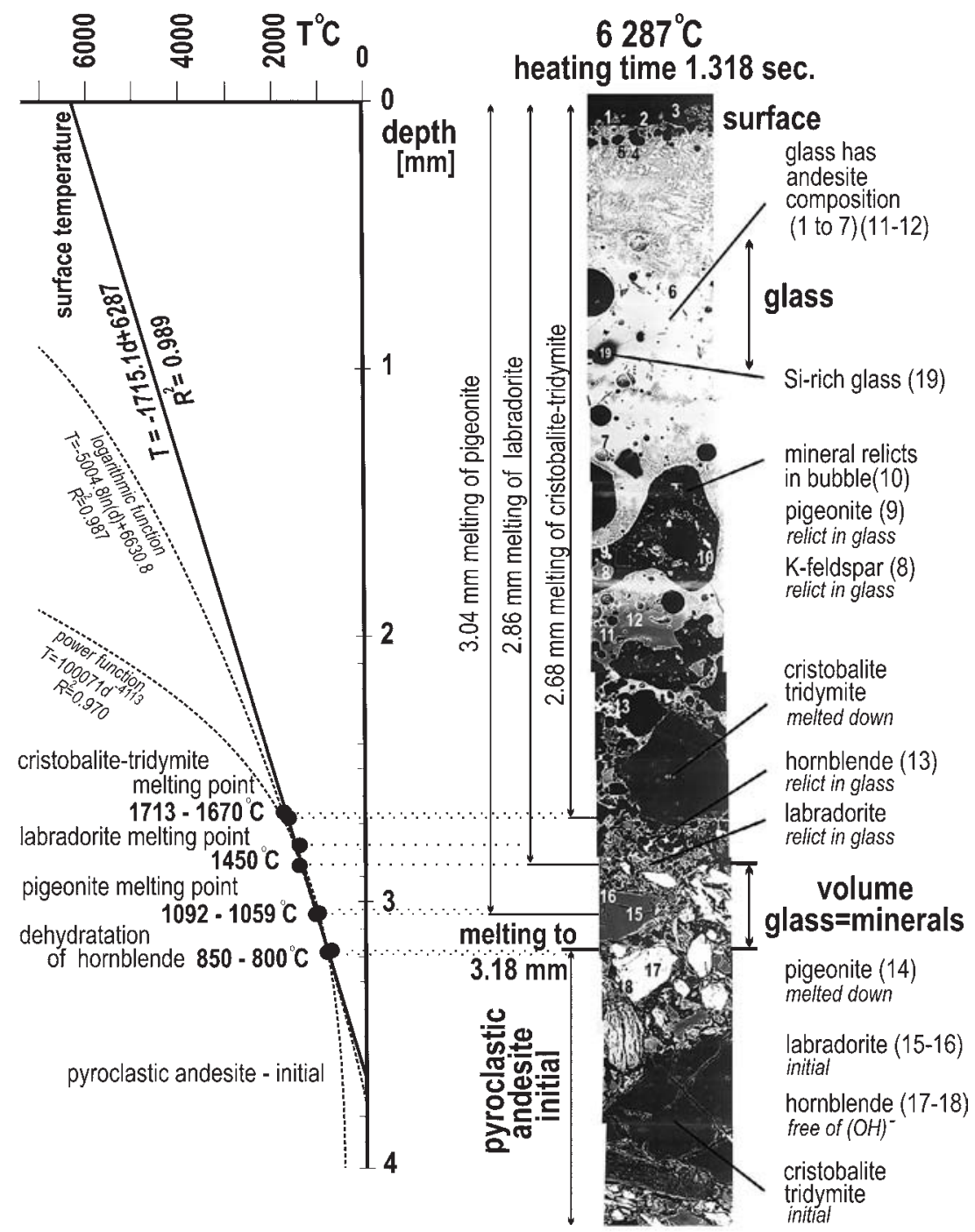

Fig. 4 Cross-section through melted pyroclastic andesite tile. The relations of average reached thickness of glass and original mineral assemblage. Backscattered electron image. The calculation of temperature $6287^{\circ} \mathrm{C}$ on the tile surface was derived by the individual mineral relicts and surrounding melt, where temperature in the melt was falling by continual proportion in dependence of depth. 1-19 are the points of analyses in Table 1.

the $\mathrm{Al}_{2} \mathrm{O}_{3}$ content ranges from 4.34 to 25.44 wt\%; $\mathrm{FeO}$ from 1.23 to $14.84 \%$; $\mathrm{MgO}$ from 0.87 to $10.28 \%$; and $\mathrm{CaO}$ from 0.81 to $9.67 \%$ (Table 1). According to the chemical classification of volcanic rocks (Le Bas et al., 1986), excepting Sirich glass $19\left(\mathrm{SiO}_{2}=91.30 \mathrm{wt} \%\right)$, the variability content of $\mathrm{SiO}_{2}$ from 52.81 to $60.91 \mathrm{wt} \%$ and $\mathrm{Na}_{2} \mathrm{O}$
$+\mathrm{K}_{2} \mathrm{O}$ from 0.77 to $6.66 \%$ shows the composition of the glass to range between andesite to basaltandesite, respectively (Fig. 3). The spot of glass (19) is located in the upper part of the glass layer ( $0.9 \mathrm{~mm}$ from the surface), where the cristobalitetridymite phenocryst was totally melted and the melt almost absorbed it. In this case, the initial 
size of $1-3 \mathrm{~mm}$ of the cristobalite-tridymite grain that usually occurred (Figs. 1 and 2) in rock was completely replaced by the heat rays forming the Si-rich glass as a spot of $0.1 \mathrm{~mm}$ in diameter (Fig. 4). Similar correlations between the composition of the glass and the initial minerals are shown in Figure 3, where the glass (4) shows the vicinity of $\mathrm{SiO}_{2}$ and $\mathrm{Na}_{2} \mathrm{O}+\mathrm{K}_{2} \mathrm{O}$ contents near the composition of hornblende, glass (6) shows the vicinity of pigeonite, glasses $(2,3,5,11$, and 12) the vicinity of labradorite, and mentioned glass (19) the vicinity of cristobalite-tridymite compositions, respectively. The comparison of $\mathrm{SiO}_{2}$ and $\mathrm{Na}_{2} \mathrm{O}+$ $\mathrm{K}_{2} \mathrm{O}$ contents of glass versus depth does not show the relation between depth of the melt and glass composition (Figs. 3 and 4).

These significant and chaotic changes in the composition of glass were mainly affected by the primary position of previously melted minerals before their total shock melting in situ. The previous and chaotic order of those minerals in pyroclastic andesite rock directly affected the random composition of different spots in the glass crust. The position of the Si-rich spot and variable glass shows that phenocrysts of the mineral were melted and consumed by a very hot melt for a period less than two seconds in situ, without a homogenization of melt during its solidification and cooling (Figs. 3 and 4).

The variable composition of glass originated from the melting of pigeonite $\left(\mathrm{X}_{\mathrm{Fe}}=\mathrm{Fe} /(\mathrm{Fe}+\right.$ $\mathrm{Mg})=0.37-0.44)$, hornblende $\left(\mathrm{X}_{\mathrm{Fe}}=0.33-0.42\right)$, labradorite $\left(\mathrm{Ab}_{48.2-40.6} \mathrm{An}_{51.8-55.5} \mathrm{Or}_{0-3.9}\right)$, K-feldspar $\left(\mathrm{Ab}_{8.2} \mathrm{Or}_{91.8}\right)$, and cristobalite-tridymite, which are present in pyroclastic andesite rock below the glass crust (Table 1). This heterogeneous glass interferes from the surface to a depth of $3.18 \mathrm{~mm}$. Below a depth of $3.18 \mathrm{~mm}$, there was neither glass nor the appearance of melting on the rim of minerals (Fig. 4).

\section{2) Pigeonite}

In the tile, the relicts of almost completely melted pigeonite were recognized to a depth of 2.86 $\mathrm{mm}$. The rim of pigeonite was notably melted at the depth interval from 2.86 to $3.04 \mathrm{~mm}$. Below this depth, the grains of pigeonite and primary pyroclastic andesite have no melted grains and retain their original hypidiomorphic forms (Fig. 4).

The lower stability limit of pigeonite or the minimum boundary of its melting temperature was determined and experimentally defined by Ishii (1975) to define the "pigeonite eutectoid reaction line" as $T=1270-480 \mathrm{X}_{\mathrm{Fe}} \pm 20$ ( $T$ in ${ }^{\circ} \mathrm{C}$ ). In the studied pyroclastic andesite rock, the minimum temperature of pigeonite melting in the extent from 1059 to $1092^{\circ} \mathrm{C}$ by following value $\mathrm{X}_{\mathrm{Fe}}(0.37-0.44)$ was calculated, according to Ishii (1975).

\section{3) K-feldspar}

The relicts of completely melted K-feldspar were found enclosed in glass and/or relicts of K-feldspar and pigeonite occurred inside the air bubbles (Fig. 4). The minimum temperature varied from 1000 to $1150^{\circ} \mathrm{C}$, which is necessary for the melting of $\mathrm{K}$-feldspar without the presence of water or for the melting of $\mathrm{K}$-feldspar that crystallized from the system $\mathrm{KAlSi}_{2} \mathrm{O}_{6}-\mathrm{SiO}_{2}$ (Schairer and Bowen, 1955; Deer et al., 1992). The range from 1000 to $1150^{\circ} \mathrm{C}$ is in agreement with that from 1059 to $1092^{\circ} \mathrm{C}$ and it was calculated as the minimum melting temperature of pigeonite. The comparison of these temperature ranges is considered as the minimum temperature needed for the melting of pigeonite and K-feldspar in tile, which goes to the lower limit of $1100^{\circ} \mathrm{C}$.

\section{4) Labradorite}

In the depth of $2.86 \mathrm{~mm}$ from the tile surface, the labradorite was totally melted and its relicts (to $3 \mu \mathrm{m}$ ) are located inside the glass in the depth from 2.79 to $2.86 \mathrm{~mm}$. In the depth from 2.86 to $3.18 \mathrm{~mm}$, the hypidiomorphic grains of labradorite were found. However, grains there occur in a thin band where the volume of the glass and the volume of minerals are equal and the melt does not cause the corrosion or melting of the labradorite rim. In the depth from 2.86 to $3.18 \mathrm{~mm}$, the temperature of the melt did not cross the minimum temperature limit of the labradorite melting point because the surface or rim of labradorite was not melted (Fig. 4-point 16, Table 1). The comparison of hypidiomorphic grains of original pyroclastic andesite to the forms of labradorite and its relicts in the melt 
indicated that labradorite was completely melted to $2.86 \mathrm{~mm}$ and its total destruction significantly contributed to the formation of melt with andesite composition (Figs. 3 and 4).

The labradorite melting point was calculated from its composition $\mathrm{Ab}_{48.2-40.6} \mathrm{An}_{51.8-55.5} \mathrm{Or}_{0-3.9}$, which is closer to $\mathrm{Ab}_{50} \mathrm{An}_{50}$. The balanced status for crystallization of plagioclase feldspar from albite $\mathrm{Ab}_{100}$ to anorthite $\mathrm{An}_{100}$ in anhydrous conditions was defined by Bowen (1913). The melting of labradorite $\mathrm{Ab}_{50} \mathrm{An}_{50}$ starts at $1450^{\circ} \mathrm{C}$, according to the equilibrium status between melt and solidus (Bowen, 1913). This is the minimum temperature needed for the melting of labradorite in the pyroclastic andesite study. It is a higher temperature than $1059-1092^{\circ} \mathrm{C}$, which was calculated for the melting of pigeonite; also, it is higher than the minimum temperature of melting for K-feldspar, which was assigned from 1000 to $1150^{\circ} \mathrm{C}$.

\section{5) Hornblende}

The relicts of melted hornblende were found from 2.68 to $3.04 \mathrm{~mm}$ depth. In this part, the primary hornblende was almost completely replaced by the melt and the size of its sporadically occurring relicts is only $5 \mu \mathrm{m}$. The part deeper than $3.18 \mathrm{~mm}$, dark brown and brown $\mathrm{Mg}$ hornblende (Leake, 1997) has hypidiomorphic form as it had in initial pyroclastic andesite and the grains are not melted on their surface (Fig. 4). $\mathrm{Mg}$ hornblende is zoned and its core has a higher $\mathrm{Si}$ (7.48 atoms pfu.) content than its rim (6.93; Table 1).

The high totals of $99.42 \mathrm{wt} \%$ and $100.26 \mathrm{wt} \%$ (analyses 18 and 17) of oxides in $\mathrm{Mg}$ hornblende show the absence of structural water in its chemical formula (Table 1). The expected range from 97.7 to $98 \%$ of the total is the usual sums of oxides in hornblende (Deer, et al., 1992, 1997).

The suitable explanation for the loss of structural water is dehydration caused by impactive heat rays. In $\mathrm{Ca}$ amphiboles (hornblende, actinolite, tremolite), the loss of water occurred in three stages: first, most of the water was absorbed, followed by the absorption of structural water in both cases at a temperature between 750 and $1000^{\circ} \mathrm{C}$, and finally a very small amount of water was absorbed (Deer et al., 1997). A DTA investigation of actinolite shows that the structural water is lost between 1060 and $1122^{\circ} \mathrm{C}$ (Vermaas, 1952) and the water is liberated between 930 and $988^{\circ} \mathrm{C}$. The water lost is marked by a strong endothermic peak DTA (Dostál, 1965). Most of the structural water was lost and the breakdown of the actinolite complete at a temperature of $850^{\circ} \mathrm{C}$ (Deer et al., 1997). The dehydration is accompanied by the breakdown of the amphibole structure; in its solid state, the original crystals of Ca amphibole (tremolite) are pseudomorphosed by $\mathrm{CaMgSi}_{2} \mathrm{O}_{3}-\mathrm{MgSiO}_{3}$ pyroxene and cristobalite (Deer et al., 1997). The thermal decomposition of tremolite into clinopyroxene confirmed $\mathrm{Xu}$ et al. (1996).

Comparing the mentioned experimental statements with the position of unmelted hornblende (17 and 18), which occurred near the melted rim of pigeonite (14) at close to $3.04 \mathrm{~mm}$ depth, the overheating of the hornblende did not exceed the amphibole melting point of $1100^{\circ} \mathrm{C}$ and/or the melting point of pigeonite $\left(1059\right.$ to $\left.1092^{\circ} \mathrm{C}\right)$ at $3.18 \mathrm{~mm}$ depth (Fig. 4). According to the abovementioned data, the sudden dehydration of hornblende was assumedly realized between 800 and $850^{\circ} \mathrm{C}$.

\section{The calculation of the temperature on the tile surface and discussion}

The extreme temperature and radiation effect of the A-bomb on the tile surface (pyroclastic andesite) was described by a temperature calculation or appraisal, which is needed for melting the pyroclastic andesite tile to the depth of $3.18 \mathrm{~mm}$. A depth of $3.18 \mathrm{~mm}$ is the lowest boundary of the melt occurrence. Below this border, labradorite, pigeonite, K-feldspar, hornblende, and cristobalitetridymite have the initial structure of mineral settings, as in pyroclastic andesite before melting. The glass is dominant above this boundary and there are no melted minerals or glass in the space among the minerals found below the boundary (Fig. 4).

The shock wave at a speed of $440 \mathrm{~m} / \mathrm{s}$ reached the surface after $1.318 \mathrm{~s}$. The tile in the hypocenter of the explosion was exposed to the direct impacts 
of the heat stream, $\gamma$-radiation, and neutron radiation, just in the time interval from 0 to 1.318 $\mathrm{s}$ after the explosion. When the wave pressure arrived, houses, roofs, and objects were destroyed but the tile was preserved in fragments of few centimetres in diameter. Only this short time interval of straight active extreme energy caused the melting of pyroclastic andesite tile down to the depth of $3.18 \mathrm{~mm}$.

The parameter of melt temperature was obtained from the melting point of cristobalite $\left(1713^{\circ} \mathrm{C}\right)$ and $/$ or tridymite $\left(1670^{\circ} \mathrm{C}\right.$; Deer et $a l ., 1992)$. The cristobalite-tridymite relicts are melted on its lower rim and the grain was found in direct contact with the glass at the depth of $2.68 \mathrm{~mm}$. Besides the melted rim, there was no other melted mineral found at this depth. It was deduced that the temperature of the melt was near $1713^{\circ} \mathrm{C}$ or close to $1670^{\circ} \mathrm{C}$ in the depth of $2.68 \mathrm{~mm}$. A few micron-sized relicts of labradorite and hornblende, which were found in the depth from $2.68 \mathrm{~mm}$ to $2.86 \mathrm{~mm}$, is the proof that at the lower rim of cristobalite-tridymite $(2.68 \mathrm{~mm})$, the temperature of the surrounding melt was higher than the labradorite $\left(1450^{\circ} \mathrm{C}\right)$ and hornblende $\left(1100^{\circ} \mathrm{C}\right)$ melting points. The melted cristobalitetridymite's lower rim at $2.68 \mathrm{~mm}$ indicates that the temperature of the surrounding melt was $1713-1670^{\circ} \mathrm{C}$. There, labradorite, pigeonite, Kfeldspar, and hornblende were completely melted at this temperature (Fig. 4).

The next important part for calculating the temperature on the surface of the tile is the depth from 2.86 to $3.18 \mathrm{~mm}$. Among these depths, the volume of glass compared to the volume of the initial mineral assemblage (rock) is equal (Fig. 4). There is unaffected labradorite, which was not influenced by surrounding melt, and it shows a temperature lower than $1450^{\circ} \mathrm{C}$ (the minimum melting temperature of the labradorite).

The depth from 2.86 to $3.18 \mathrm{~mm}$ represents the zone where the melt caused melting of the pigeonite rim. According to this finding, the melt temperature in the part from 2.86 to $3.04 \mathrm{~mm}$ was in the range from 1092 to $1059^{\circ} \mathrm{C}$. This explains why the labradorite grain was not melted, but the rim of pigeonite was melted in the depth mentioned above (Fig. 4). The approximate stability between the labradorite relict and the surrounding melt occurred on the rim of its grain in $2.86 \mathrm{~mm}$ in close extent from 2.79 to $2.86 \mathrm{~mm}$. The temperature of the melt was equal to the labradorite melting point of $1450^{\circ} \mathrm{C}$. It is a lower temperature than the minimum cristobalitetridymite melting point $\left(1713-1670^{\circ} \mathrm{C}\right)$ on its grain-rim at $2.68 \mathrm{~mm}$. The above evidence of temperature drop with depth indicated the dehydration of hornblende at a depth of $3.18 \mathrm{~mm}$, which is also important at this depth and was decreased as the temperature varied from 800 to $850^{\circ} \mathrm{C}$. From this depth and lower, no glass or melted minerals on its rim were found.

According to the above data about melted cristobalite-tridymite at $2.68 \mathrm{~mm}$ and its melting temperature from 1713 to $1670^{\circ} \mathrm{C}$, the relation of the regressive lines of temperature drop on a continuous proportion to depth was calculated from a position of melted labradorite between a depth of 2.79 and $2.89 \mathrm{~mm}$ by a temperature of $1450^{\circ} \mathrm{C}$. The next points on the continual temperature drop proportion show melted pigeonite at 3.04 $\mathrm{mm}$, its melting temperature from 1092 to $1059^{\circ} \mathrm{C}$, and the final drop point defines the position of the first dehydrated amphibole by a temperature of 800 to $850^{\circ} \mathrm{C}$ in $3.18 \mathrm{~mm}$ of depth.

According to the dispersion of eight melting points in a depth from 2.68 to $3.18 \mathrm{~mm}$, the surface temperature was calculated as a dependence of decreased temperature $(T)$ to depth $(d)$. Dependence was calculated by the power function $\left(T=100071 d^{-4113} ; R^{2}=0.970\right)$, by a logarithmic function $\left(T=-5004 \ln (d)+6630.8 ; R^{2}=0.987\right)$, and by linear regression $(T=-1715.1 d+6287$; $R^{2}=0.989$ ). The conduction of the heat from the surface to depth was controlled by linear regression because of the high coefficient of correlation $\left(R^{2}\right)$. The temperature on the tile surface was $6287^{\circ} \mathrm{C}$ (Fig. 4). A logarithmic or a power distribution of the temperature drop was not found in the profile of pyroclastic andesite rock. Similar linear but reverse behavior is observed when the temperature is systematically increased with depth. This rate of increase in temperature per unit depth is known as the geothermal gradient of 
the rocks. The systematic decreased temperature depending on depth shows that the pyroclastic andesite rock absorbed the heat of $1715^{\circ} \mathrm{C} / \mathrm{mm}$ in a period less than two seconds. According to linear regression and calculation, any changes cannot be assumed on the mineral assemblage at a depth below $3.64 \mathrm{~mm}$. This was confirmed by mineralogical research as well. There was no melted minerals found, nor was there any presence of the melt or glass at this depth (Fig. 4).

The systematic absorption of the extreme energy formed the consistent melting that begins from the surface and ends at a depth of 3.18 $\mathrm{mm}$. The temperature of the melt systematically decreases in its crust as well. The sudden consumption of the energy during $1.318 \mathrm{~s}$ and the extreme contrast between the temperature at the surface $\left(6287^{\circ} \mathrm{C}\right)$ and temperature inside the tile (possibly $30^{\circ} \mathrm{C}$ ) resulted in overheating and rapid migration of the air towards the melt or surface. It is well known that primary pyroclastic andesite rock contains an amount of air that had been captured and bonded in mineral spaces during the cooling of the andesitic magma. The bonded air has been abruptly released by the shock heat rays from the mineral space in the tile. This very hot air migrated into the melt on the surface, forming air bubbles in the iced melt (Figs. 2 and 4). The released air made the undulated surface and glass peaks over the primary surface $(1 \mathrm{~mm})$, and the empty air bubbles must be considered as part of the volume of the previous pyroclastic andesite rock.

The sudden liberation and migration of the air probably incurred a homogenization of the temperature at the beginning of cooling in the melt. However, the homogenization of melt composition failed because glass has wide chemical heterogeneity (Fig. 3). This means that boiling the melt was not achieved because the melted fragments were suddenly cooled in the Motoyasu River. Fragments of melted tiles were carried by the shock wave from the hypocenter area to the river in less than one second $(0.34 \mathrm{~s})$ because the distance from the hypocenter to the river is about $150 \mathrm{~m}$ and the speed of shock wave was $440 \mathrm{~m} / \mathrm{s}$. After the set of melted fragments in the river, the melt was iced by the water during a short time. This is the best explanation of why the glass composition is wide. If the melted surface had been gradually cooled during a long time (hours) above ground, the boiling of the melt should have produced a homogenized glass. Cooling the melt for a long time would wipe away the relationship between minerals and glass, in this case, and disable studying it in detail.

\section{Conclusion}

The surface temperature of the two atomicbombed andesite tiles (pyroclastic andesite) in Hiroshima was deduced from the relationship between the depth of their melted surface and different melting points of cristobalite-tridymite, pigeonite, K-feldspar, labradorite and hornblende, the minerals that were found in the tile fragments. The surfaces of tiles were melted to a depth of $3.18 \mathrm{~mm}$ by the heat rays. The linear relationship between temperature $(T)$ and depth $(d) T=-1715.1 d+6287$ were obtained in the part from 2.68 to $3.18 \mathrm{~mm}$ of depth and the extrapolation of the relationship suggests the surface temperature of $6287^{\circ} \mathrm{C}$ in hypocenter of the A-bomb explosion. The short absorbed time of heat ray $(1.318 \mathrm{~s})$ and rapid cooling after next short time $(0.34 \mathrm{~s})$ by the river water (Motoyasu River) preserved the compositional heterogeneity of the melted glass on the tile surface. The crust of glass has a wide composition, where the $\mathrm{Al}_{2} \mathrm{O}_{3}$ content ranges from 4.34 to $25.44 \mathrm{wt} \% ; \mathrm{FeO}$ ranges from 1.23 to $14.84 \%$; $\mathrm{MgO}$ from 0.87 to $10.28 \%$; and $\mathrm{CaO}$ from 0.81 to $9.67 \%$. According to the chemical classification of volcanic rocks, the variability content of $\mathrm{SiO}_{2}$ from 52.81 to 60.91 wt $\%$ and $\mathrm{Na}_{2} \mathrm{O}+\mathrm{K}_{2} \mathrm{O}$ from 2.46 to $6.66 \%$ shows a range in glass composition from andesite to basaltic andesite rocks or the Si-rich glass that has been found, respectively. The significant and chaotic changes in the composition of the glass were mainly effected by the primary position of previously melted minerals in the pyroclastic andesite before its shock melting.

\section{Acknowledgments}

I would like to express my gratitude to students from 
the high school affiliated with the Hiroshima Denki Institute of Technology (currently Hiroshima Kokusai Gakuin High School) and their instructor Mr. Nobuyuki Ookame for precise selection of andesite tile samples. The students significantly inspired the result of this study by finding suitable samples from the period of 1977 to 1982 . My thanks also goes to Prof. S. Banno, Mrs. F. Kuwahara, Prof. I. Nakanishi, Dr. J. Král, Prof. M. Torii, four anonymous reviewers and my daughter Jana for their reflections and help in this study. I have to also thank Mr. Nobuyuki Ookame for his help to find Japanese scientific reports and letters.

\section{References}

Bowen, N.L. (1913): The melting phenomena for the plagioclase feldspars. American Journal of Science, 4th ser., 35, 557-599.

Burr, W. (2007): The atomic bomb and the end of World War II; A collection of primary sources. National Security Archive Electronic Briefing Book No. 162. 202/994-7000.

Deer, W.A., Howie, R.A. and Zussman, J. (1992): An Introduction to the Rock-Forming Minerals (2nd ed.). Longman Scientific \& Technical.

Deer, W.A., Howie, R.A. and Zussman, J. (1997): RockForming Minerals, v.2A. Single-Chain Silicates (2nd ed.). The Geological Society London.

Dostál, J. (1965): Mineralogical and chemical investigation of actinolite from Sobutín, Czechoslovakia. Acta Universitatis Carolinae Geologica, 3, 31-35. (English abstract)

Glasstone, S. and Dolan, P.J. comp. eds. (1977): The Effects of Nuclear Weapons (3rd ed.). United States Department of Defense and the Energy Research and Development Administration.

Hashiguchi, R. (1953): Stenographic records of the 2nd Report Meeting of Special Committee for Investigation on Atomic Bomb Disaster, Engineering and metalworking division. Collection of Investigation Reports on Atomic Bomb Disaster (v.1), 46. In Japanese: 橋口 隆吉 (1953): 原子爆弾災害調査研究特別委員会第 2 回 報告会速記録機械金属学科会. 原子爆弾災害調査報告 集 (第 1 分冊)，46.

Hiroshima Peace Memorial Museum (1994): The Outline of Atomic Bomb Damage in Hiroshima. Hiroshima Peace Memorial Museum.

Hiroshima-shi, Nagasaki-shi Genbaku Saigaishi Henshu Iinkai (Committee for the Record of the Hiroshima and Nagasaki A-bomb Casualty) ed. (1979): Atomic Bomb Casualty of Hiroshima and Nagasaki. IwanamiShoten. In Japanese: 広島市・長崎市原爆災害誌編集 委員会編 (1979): 広島・長崎の原爆災害. 岩波書店.

Hirschfelder, J.O., Parker, D.B., Kramish, A., Smith, R.C. and Glasstone, S. ed. (1950): The Effects of Atomic Weapons (prepared for and in cooperation with the U.S. Department of Defense and the U.S. Atomic Energy Commission, under the direction of the Los Alamos Scientific Laboratory, Los Alamos, New Mexico). McGraw-Hill.

Ishibashi, K. (1971): Petrochemical study of basaltic rocks from Higashimatsuura and Ikutsuki-jima district, Northern Kyushu, Japan. Science Reports, Department of Geology Kyushu University, 10, 177221. (in Japanese with English abstract)

Ishii, T. (1975): The relations between temperature and composition of pigeonite in some lavas and their application to geothermometry. Mineralogical Journal, Japan, 8, 48-57.

Ito, T. and Morimoto, N. (1956): Pseudotwins in certain pyroxenes. Jubilee Publication in Commemoration of the Sixtieth Birthday of Professor Jun Suzuki. M.J.A. Sapporo, Japan, 337-341. (in Japanese with English abstract)

Kamada, N. (2005): A Grandmother in Hiroshima Past, Present and Future. High School Textbook. ShiftProject. (in Japanese)

Kuno, H. (1950): Petrology of Hakone volcano and the adjacent areas, Japan. Bulletin, Geological Society of America, 61, 947-1019.

Le Bas, M.J., Le Maitre, R.W., Streckeise, A. and Zanettin, B. (1986): A chemical classification of volcanic rocks based on the total alkali-silica diagram. Journal of Petrology, 27, 745-750.

Leake, B.E. (1997): Nomenclature of amphiboles: Report of the Subcommittee on Amphiboles of the International Mineralogical Association, Commission on New Minerals and Mineral Names. American Mineralogist, 82, 1019-1037.

Majima, M., Tsutsui, S. and Kan, Y. (1953): Radiation temperature and blast wave in Hiroshima and Nagasaki. Collection of Investigation Reports on Atomic Bomb Disaster (v.1, Science and Engineering Section), 183. In Japanese: 眞島正市・筒井俊正・管 義夫 (1953): 広島長崎における輻射温度および爆風圧. 原子爆弾災害調査報告集 (第 1 分冊理工学編), 183.

Manhattan Engineer District (1946): The Atomic Bombings of Hiroshima and Nagasaki. A Penn State Electronic Classics Series Publication.

Nishina, Y. ed. (1951): General reports of investigation of science and engineering division. Special Committee for Investigation on Atomic Bomb Disaster, National Research Council of Ministry of Education. Collection of Investigation Reports on Atomic Bomb Disaster (Summary Part), 116. In Japanese: 仁科芳雄編 (1951): 文部省学術研究会議 原子爆弾災害調査研究特別委員会 調查総合報告書理工学科編. 原子爆弾災害調査報告書 (総括編), 116.

Schairer, J.F. and Bowen, N.L. (1955): The system $\mathrm{K}_{2} \mathrm{O}$ $\mathrm{Al}_{2} \mathrm{O}_{3}-\mathrm{SiO}_{2}$. American Journal of Science, 253, 681746.

Sekimori, G. (1989): Hibakusha: Survivors of Hiroshima and Nagasaki. C.E. Tuttle. 
Selden, K. and Selden, M. (1997): The Atomic Bomb: Voices from Hiroshima and Nagasaki. M.E. Sharpe.

Shohno, N., Takeshita, K. and Okajima, S. (1978): Physical destruction and human casualties caused by the Atomic bombs. A Call from Hibakusha of Hiroshima and Nagasaki. Proceedings [of the] International Symposium on the Damage and Aftereffects of the Atomic Bombing of Hiroshima and Nagasaki, July 21-August 9, 1977, Tokyo, Hiroshima and Nagasaki, 75-82.

Tanaka, Y. (1953): Stenographic records of the 2nd Report Meeting of Special Committee for Investigation on Atomic Bomb Disaster, Civil engineering and construction division. Collection of Investigation Reports on Atomic Bomb Disaster (v.1), 47. In Japanese: 田中 豊 (1953): 原子爆弾災害調査研究特別委員会第 2 回 報告会速記録土木建築学科会. 原子爆弾災害調査報告 集 (第 1 分冊), 47.

Tsutsui, T. (1953): Stenographic records of the 1st Report Meeting of Special Committee for Investigation on Atomic Bomb Disaster, Engineering and metalworking division. Collection of Investigation Reports on Atomic Bomb Disaster (v.1), 24. In Japanese: 筒井 俊正 (1953): 原子爆弾災害調査研究特別委員会第 1 回 報告会速記録機械金属学科会. 原子爆弾災害調査報告 集 (第 1 分冊)， 24.

Tsuzuki, M. ed. (1951): Reports of investigation of Medical division. Special Committee for Investigation on Atomic Bomb Disaster, National Research Council of Ministry of Education, vol. 1. Research records of investigation on Atomic Bomb Disaster. Collection of Investigation Reports on Atomic Bomb Disaster (Summary Part), 3. In Japanese: 都築正男編（1951）: 文部省学術研究会議 原子爆弾災害調査研究特別委員会 医学科会報告書 第 1 編原子爆弾災害調査研究成績. 原 子爆弾災害調査報告書 (総括編)，3.

Vermaas, F.H.S. (1952): The amphibole asbestos of South Africa. Transact of the Geological Society of South Africa, 55, 1-42.

Watanabe, T., Yamazaki, M., Kojima, J., Nagaoka, S. and Hirayama, K. (1953): Geological and petrographical observation on Atomic bomb disaster in Hiroshima and Nagasaki. Collection of Investigation Reports on Atomic Bomb Disaster (v.1, Science and Engineering Section), 143-158. In Japanese: 渡辺武男 · 山崎正男 · 小島丈児・長岡省吾・平山 健 $(1953)$ : 広島および 長崎両市における原子爆弾災害物の地質学および岩石 学的観察. 原子爆弾災害調査報告集 (第 1 分冊理工学 編), 143-158.

Xu, H., Veblen, D.R., Luo, G. and Xue, J. (1996): Transmission electron microscopy study of the thermal decomposition of tremolite into clinopyroxenite. American Mineralogist, 81, 1126-1132.

(Received 14 November, 2007; Accepted 27 July, 2009) 


\title{
原子爆弾炸裂後 $\mathbf{2}$ 秒間での火山砕屑安山岩瓦の融解
}

\author{
一広島 1945 年 8 月 6 日午前 8 時 15 分一
}

\section{Martin RADVANEC *}

この研究は, 1945 年 8 月 6 日, 午前 8 時 15 分, 広島の原子爆弾爆発による熱線の強力な影響を, 2 片の被爆瓦片を用いて研究したもので，この瓦 片は元安川に架かる元安橋下流約 $100 \mathrm{~m}$ の西岸で 1977 ～ 1982 年にかけて発掘されたものである。 爆発から 1.318 秒後, 爆心地で破壊された建物か ら衝撃波によって吹き飛ばされた大変熱くて融解 した多数の破片は, 元安川西岸に堆積した。この 瓦片はおそらく, 破壊された清病院の石塀, 西向 寺および (もしくは) 西蓮寺からのもので, 川の 水で急激に冷却されたものと思われる。

瓦片は安山岩質の火山砕首岩からなり, その表 面は $3.18 \mathrm{~mm}$ の梁さまで融解していた。そのガ ラス質の層は, 安山岩から玄武岩質安山岩の組 成をもつ。これらはクリストバル石および/もし くはリンケイ石, ピジョン輝石 $\left(\mathrm{X}_{\mathrm{Fe}}=\mathrm{Fe} /(\mathrm{Fe}+\right.$ キーワード：広島, 原子爆弾, 爆心地, 温度
$\mathrm{Mg})=0.37-0.44)$, 角閃石 $\left(\mathrm{X}_{\mathrm{Fe}}=0.33-0.42\right)$, 曹 灰長石 $\left(\mathrm{Ab}_{48.2-40.6} \mathrm{An}_{51.8-55.5} \mathrm{Or}_{0-3.9}\right)$ および $\mathrm{K}$ - 長石 $\left(\mathrm{Ab}_{8.2} \mathrm{Or}_{91.8}\right)$ が融解生成したものである。融解が $3.18 \mathrm{~mm}$ の深さにまでおよんでいることと, 上記 鉱物質のそれぞれ異なる融点および溶融深度から, 爆発後の爆心地の物体表面の温度 $6287^{\circ} \mathrm{C}$ が算出さ れた。この表面温度は，深さ $2.68 \sim 3.18 \mathrm{~mm}$ の 区間における残存鉱物と, 溶融深度の関係から導 き出した。回帰直線 $T=-1715.1 d+6287(d$ は 深さ） $\left(R^{2}=0.989 ）\right.$ を外抻して求めたものである。 安山岩瓦表層部の温度勾配は $1 \mathrm{~mm}$ あたり $1715^{\circ} \mathrm{C}$ で，深さが $2.86 \mathrm{~mm}$ から $3.18 \mathrm{~mm}$ の間では，融 解ガラス質と本来の鉱物質は等量である。 $3.64 \mathrm{~mm}$ 以下では，火山砕屑安山岩の構造および鉱物組成 は，本来の組成を有している。

\footnotetext{
* State Geological Institute of Dionýz Štúr
} 